\title{
Evidence for Different Gestation-Dependent Effects of Cortisol on Cultured Fetal Lung Cells
}

\author{
Barry T. Smith, John S. Torday, and C. J. P. Giroud \\ From the Department of Experimental Medicine, McGill University and The \\ McGill University-Montreal Children's Hospital Research Institute, \\ Montreal, Canada $\mathrm{H} 3 \mathrm{H} 1 \mathrm{P3}$
}

A B S T R A C T The effect of cortisol $(5.5 \mu \mathrm{M})$ on primary monolayer cultures of trypsin-dispersed lung cells from rabbit fetuses of 20-28 days gestation was monitored with respect to $(a)$ cellular growth as determined by DNA content after $72 \mathrm{~h}$, at which time all cultures were in the exponential phase of growth, and $(b)$ cellular maturation as reflected by the incorporation of $\left[{ }^{14} \mathrm{C}\right]$ palmitate into saturated lecithin and its release into the culture medium.

Cortisol significantly increased growth in cultures prepared from 20 day (control: $59.8 \pm 8.9 \mathrm{nmol} \mathrm{DNA} /$ flask; cortisol: $118.7 \pm 15.7, P<0.001$ ) and 22 day (control: $69.2 \pm 17.2$; cortisol: $106.7 \pm 13.3, P<0.001$ ) fetuses but had no effect on the growth of cells from 24 or 26 day fetuses. At 28 days, the effect was reversed, cortisol reducing growth by a factor of two (control: $42.0 \pm$ 8.5 ; cortisol: $19.3 \pm 4.0, P<0.001)$.

Incorporation of palmitate into lecithin was expressed as picomoles incorporated per micromole DNA per flask, thus correcting for differences in the number of cells. Cortisol had no effect on palmitate incorporation until day 26 , at which time it caused a slight increase (control: 51.2 \pm 5.5 ; cortisol: $72.8 \pm 16.2, P<0.01$ ) which became very striking by day 28 (control: $19.7 \pm 3.1$; cortisol; 286.8 $\pm 47.0, P<0.001$ ). The proportion of recovered radiolabeled lecithin that was disaturated rose with gestational age from $72 \%$ at 20 days to $98 \%$ at 28 days. Saturated lecithin made up over $90 \%$ at the two gestational ages (26 and 28 days) where cortisol increased palmitate incorporation. In contrast, cortisol had no effect on the incorporation of palmitate into sphingomyelin at any of the gestational ages studied.

The results suggest that cortisol may increase fetal pulmonary cellular growth in early gestation while en-

Dr. Giroud is a Medical Research Associate of the Medical Research Council of Canada.

Received for publication 29 August 1973 and in revised form 2 January 1974. hancing maturation and slowing growth as term approaches.

\section{INTRODUCTION}

Numerous studies have established that mammalian lung alveoli are lined with a highly surface active substance, generally referred to as the pulmonary surfactant, which reduces surface tension at low lung volumes, preventing alveolar collapse at end-expiration $(1,2)$. Analysis of this material has established its nature as a lipoprotein with a high content of dipalmityl lecithin (3).

During late gestation the fetal lung undergoes important anatomical and biochemical changes associated with the appearance of the pulmonary surfactant (3) and with the eventual role of the lung as an organ of gas exchange. In recent years experimental evidence has accumulated that indicates that administration of steroids possessing various glucocorticoid potencies hastens some of these maturational processes. Thus, after the administration of pharmacological doses of glucocorticoids, enhancement of pulmonary maturation was observed in the fetal lamb (4), rabbit (5-7), and Rhesus monkey (8). Along these same lines, Farrell and Zachman (9) have shown that administration of cortisol (11 $\beta, 17 \alpha, 21$-trihydroxypregn-4-ene-3,20-dione) and cortisol analogues to the fetal rabbit markedly increases the specific activity of lung cytidine diphosphocholine transferase, an enzyme that catalyses the rate-limiting step in the incorporation of choline into lecithin.

The potential relevance of such observations to respiratory function in the human newborn has stimulated interest at the clinical level (10-12). Results up to now have been somewhat inconclusive. Although the administration of pharmacological doses of betamethasone to the mother in premature labor, for at least $24 \mathrm{~h}$ before parturition, appeared to lead to a decreased incidence of the respiratory distress syndrome in the off- 
spring of less than 32 wk gestation (10), equally high doses of cortisol hemisuccinate were ineffective in altering the course of the disease when administered to the newborn infant in a double-blind controlled study (12). However, in themselves, these negative findings need not be interpreted as contrary to the view that endogenous cortisol, whether of fetal or maternal origin, may play an important role in the development of the lung under normal intrauterine conditions. The recent observations of specific receptors for cortisol (and dexamethasone) in both the cytosol (13) and nuclear (14) fractions of fetal lung homogenates present strong evidence that the lung might be an important target tissue for these steroids.

We have previously reported that in a primary monolayer tissue culture system cortisol enhanced the growth of human midterm fetal lung cells (15). The present investigations were initiated to study further the relevance of these observations as a function of gestational age, using the rabbit as a model because of its short gestation. Measuring DNA accumulation as an index of cell growth and lecithin biosynthesis as an index of maturation, the results provide evidence of a dual mechanism of cortisol action during fetal lung development.

\section{METHODS}

Materials. Ham's F 10 tissue culture medium (16) was purchased from Microbiological Associates, Inc., Bethesda, Md., and supplemented with $10 \%$ fetal calf serum (Flow Laboratories, Inc., Rockville, Md.), penicillin (100 $\mathrm{U} / \mathrm{ml}$ ) (Therapex, Montreal, Canada), gentamicin (10 $\mu \mathrm{g} /$ $\mathrm{ml}$ ) (Roussel Laboratories, Montreal, Canada), and amphotericin B $(5 \mu \mathrm{g} / \mathrm{ml})$ (E. R. Squibb \& Sons, Montreal, Canada). This preparation will subsequently be referred to as "tissue culture medium." The fetal calf serum provides the tissue culture medium with traces of cortisol $(1.4 \mathrm{nM})$ and corticosterone (11 $\beta, 21$-dihydroxypregn-4-ene$3,20$-dione) ( $0.3 \mathrm{nM})$ as measured by competitive protein binding assay after separation of these steroids by paper chromatography as previously reported (17). Trypsin (1: 250) was purchased from Difco Laboratories, Detroit, Mich. Krebs-Ringer bicarbonate buffer (18) with $200 \mathrm{mg}$ of glucose per $100 \mathrm{ml}$ (KRBG) ${ }^{1}$ was prepared by omitting calcium chloride in order to facilitate cell dispersion (19, p. 131).

Cortisol was purchased from Steraloids Inc., Pawling, N. Y., and added to the culture medium at a concentration of $5.5 \mu \mathrm{M}$. The required amount of the steroid was transferred to a flask in ethanol. The ethanol was evaporated to dryness under a stream of air, and the appropriate volume of culture medium was added to obtain the concentration quoted above. The flask was mechanically agitated for $2 \mathrm{~h}$. The medium with added steroid was then sterilized by pressure filtration through a Millipore filter (Millipore Corp., Bedford, Mass.) with a pore diameter of 0.22 $\mu \mathrm{m}$. Model experiments using $\left[{ }^{14} \mathrm{C}\right]$ cortisol showed that

${ }^{1}$ Abbreviation used in this paper: KRBG, Krebs-Ringer bicarbonate buffer (18) with $200 \mathrm{mg}$ of glucose per $100 \mathrm{ml}$. under such conditions quantitative solubilization was achieved.

$\left[1-{ }^{14} \mathrm{C}\right]$ palmitic acid (sp act $40 \mathrm{mCi} / \mathrm{mmol}$ ) was purchased in hexane from New England Nuclear, Boston, Mass., and its radiochemical purity was tested by thinlayer chromatography in the system quoted below. From this stock solution appropriate aliquots were taken, dried under a stream of air, and redissolved in $1 \mathrm{~N}$ sodium hydroxide. The solution was boiled in a water bath for 30 min to convert the palmitic acid to its sodium salt. The $\mathrm{pH}$ of the solution was adjusted to 7 with $1 \mathrm{~N}$ hydrochloric acid, and 4\% (wt: vol) human serum albumin was added to facilitate solubilization.

DEAE-cellulose was obtained from $W$. and R. Balston, Ltd., Maidstone, Kent, England, and glass plates precoated with Silica Gel $\mathrm{H}$ were purchased from Brinkman Instruments, Rexdale, Canada.

Biological material. Pregnant white New Zealand rabbits (Canadian Breeding Farms, St. Constant, Quebec, Canada) of known time of gestation were obtained at 20-28 days of gestation. The does were sacrificed with a lethal intravenous dose of pentobarbital, and the gravid uterus was rapidly exposed. The fetuses were removed under sterile conditions, sacrificed by decapitation, and placed in KRBG at $4^{\circ} \mathrm{C}$. The thoraces were opened by a midline sternal incision and the fetal lungs were removed and dissected free of large bronchi. The tissue was minced, washed repeatedly with cold buffer, and resuspended in 10-15 ml of buffer per $g$ (wet wt) tissue, containing trypsin at the concentration of $250 \mathrm{mg} / 100 \mathrm{ml}$. The mixture was stirred on a magnetic stirrer at $37^{\circ} \mathrm{C}$ until no visible tissue fragments remained (depending on gestational age this took from $15 \mathrm{~min}$ for 20 day fetal lungs to $55 \mathrm{~min}$ for 28 days). From the time of hysterotomy, the above procedures were carried out under a laminar flow hood (Canadian Cabinets, Montreal, Canada). The enzyme hydrolysate was filtered through four layers of cotton gauze, and the filtrate was centrifuged for $10 \mathrm{~min}$ at $200 \mathrm{~g}$ in an International Centrifuge (International Equipment Co., Needham Heights, Mass.) operated at room temperature. In order to remove traces of trypsin, the cells were twice resuspended in fresh buffer and recentrifuged. After the second wash, the cell pellet was resuspended in culture medium, the volume of which was adjusted to contain approximately $5 \times 10^{5}$ cells per $\mathrm{ml}$, as estimated in a hemocytometer.

1-ml aliquots of this suspension were transferred into individual plastic culture flasks (Falcon Plastics, Division of BioQuest, Oxnard, Calif.) with a surface area of 25 $\mathrm{cm}^{2}$, each containing $4 \mathrm{ml}$ of culture medium with or without added cortisol. The flasks were flushed with $5 \% \mathrm{CO}_{2}$ in air for $10 \mathrm{~s}$, sealed, and stored in an incubator at $37^{\circ} \mathrm{C}$. The culture media were changed $24 \mathrm{~h}$ after implantation.

Assessment of cellular growth. Cell growth was determined after $72 \mathrm{~h}$ in culture. The media were decanted, and the flasks were washed twice with $2 \mathrm{ml}$ of isotonic saline. The cells were detached from the surface of the flasks with the aid of a rubber policeman and repeatedly rinsed from the flasks with saline. The efficiency of this procedure was checked by microscopic examination of the culture flasks which revealed that cell removal was virtually complete. The cells were centrifuged for $5 \mathrm{~min}$ at $1,000 \mathrm{~g}$, and the pellet was resuspended in $0.5 \mathrm{ml}$ of $5 \%$ perchloric acid. Total DNA content was determined by the diphenylamine colorimetric reaction of Burton (20) which measures the deoxyribose moiety of DNA, using calf thymus DNA (Canadian Laboratory Supplies, Quebec, Canada) as standard. 
Assessment of the biosynthesis of phospholipids. After $48 \mathrm{~h}$ in culture, $0.1 \mu \mathrm{Ci}$ of $\left[1-{ }^{14} \mathrm{C}\right]$ sodium palmitate was added to the medium of each culture. After incubation for $24 \mathrm{~h}$, the incorporation of palmitate into lecithin and sphingomyelin was determined in the culture media alone. The cells were processed for DNA as described above.
The media were diluted with 1 vol of methanol. The methanol-water phase was extracted with 2 vol of chloroform, and the chloroform extracts were processed by following the methods of Gluck, Kulovich, and Brody (21) without modification. The lipid extracts were initially subjected to DEAE-cellulose acetate microcolumn chroma-
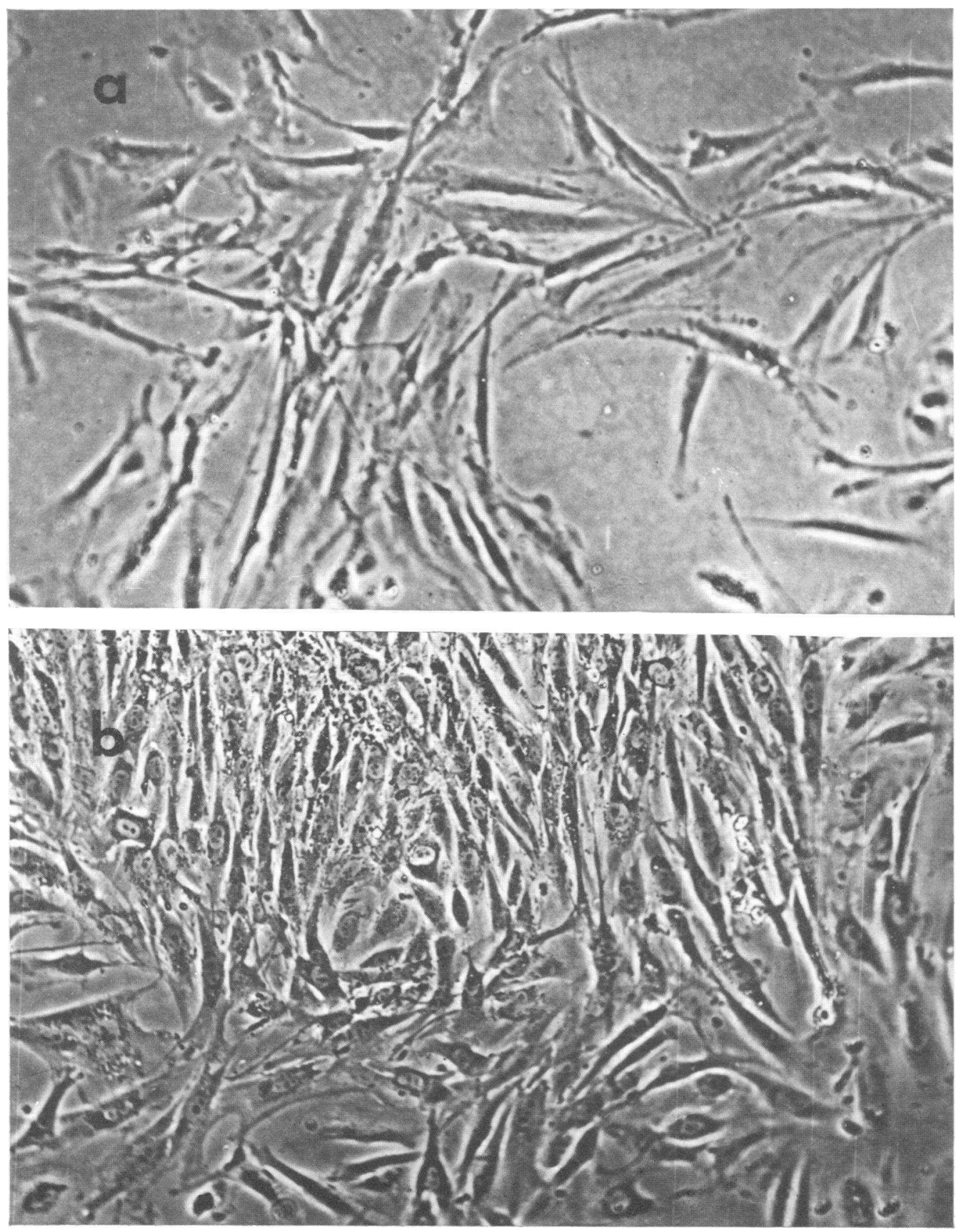

FIGURE 1 Phase contrast photomicrograph of cells prepared from 20 day fetal rabbit lungs and maintained in monolayer culture for $72 \mathrm{~h}$. (a) Cells grown in control medium; (b) cells grown in the presence of cortisol $(5.5 \mu \mathrm{M})$. The predominant fibroblastic nature of these cells and the growth promoting effect of cortisol $(b)$ are clearly evident. $\times 100$. 

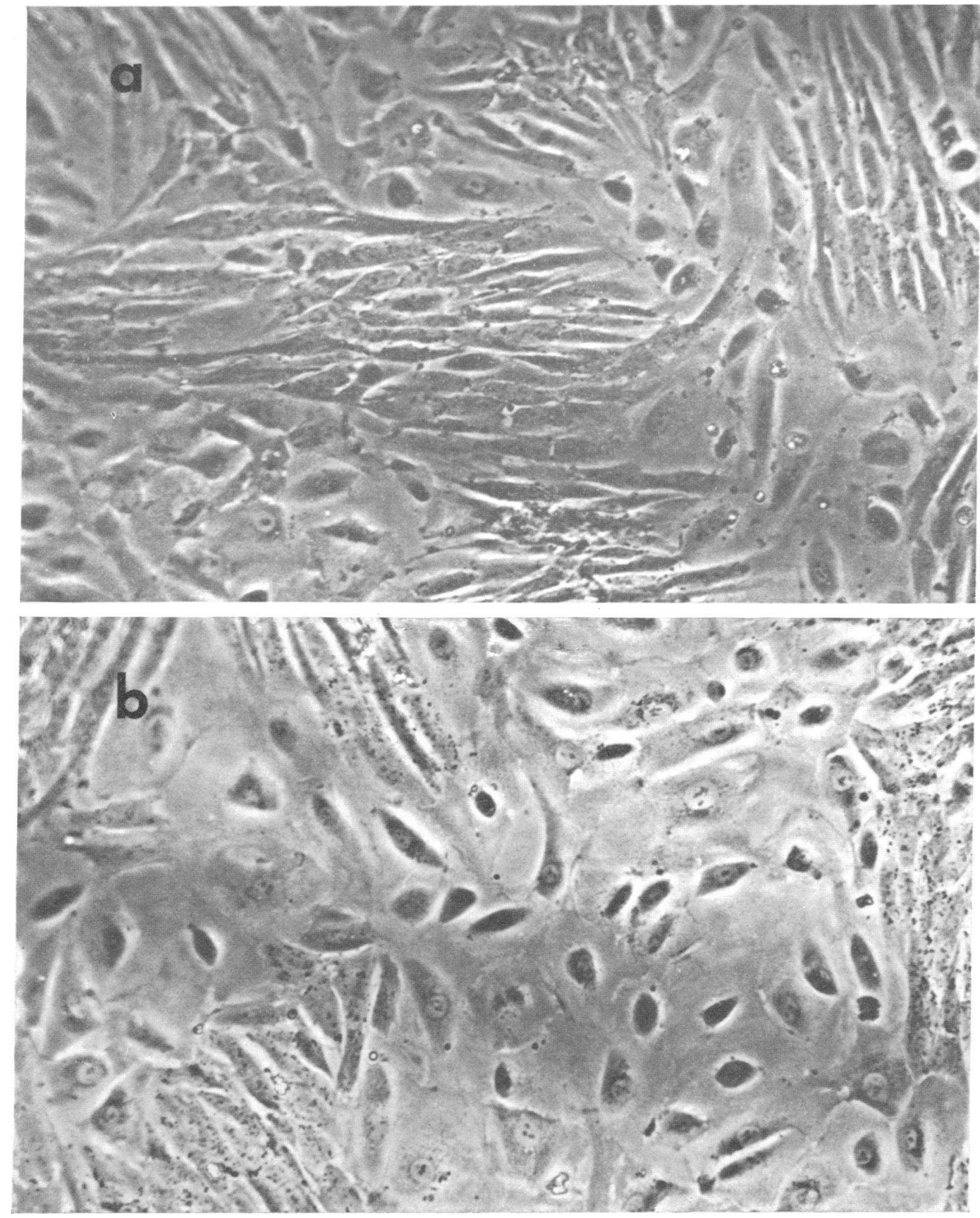

FIGURE 2 Phase contrast photomicrograph of cells prepared from 28 day fetal rabbit lungs and maintained in monolayer culture for $72 \mathrm{~h}$. (a) Cells grown in control medium; $(b)$ cells grown in the presence of cortisol $(5.5 \mu \mathrm{M})$. There is a mixed population of cell types with an apparent increase in the proportion of "epithelial" cells in the presence of cortisol (b). $\times 200$.

tography to separate acidic from nonacidic phospholipids. Negligible radioactivity was detected in the acidic fractions. The nonacidic phospholipid eluates were purified by thinlayer chromatography on Silica $\mathrm{Gel} H$ in the system chloroform: methanol: water $(65: 25: 4)$ (21). The plates were autoradiographed for $18 \mathrm{~h}$ by using standard radiology cassettes and films. Radioactive areas were eluted with the solvent system.

After appropriate aliquots were taken for counting, the crude lecithin fractions were further purified into satu- 


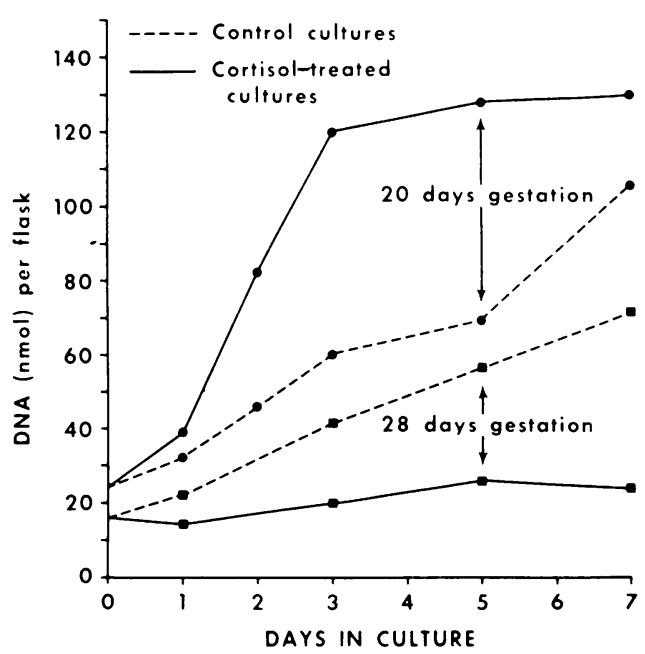

Figure 3 Growth curves (expressed as nanomoles DNA per flask at various times after implantation) for 20 (๑) and 28 (ם) day rabbit fetal lung cells grown in the presence (solid line) and absence (dotted line) of cortisol $(5.5 \mu \mathrm{M})$. The positive effect of cortisol on cellular growth at 20 days and its negative effect at 28 days can be seen. The curves show that differences in DNA content at $72 \mathrm{~h}$ reflect differences in growth rate.

rated and unsaturated fractions. The crude lecithin samples were pooled into cortisol-treated and control groups for each gestational age and reacted in $5 \mathrm{ml}$ of a saturated methanolic solution of mercuric acetate as described by Mangold (22). The flasks were tightly stoppered and kept in the dark at room temperature for $24 \mathrm{~h}$. The methanol was evaporated to dryness, and the residue was re-

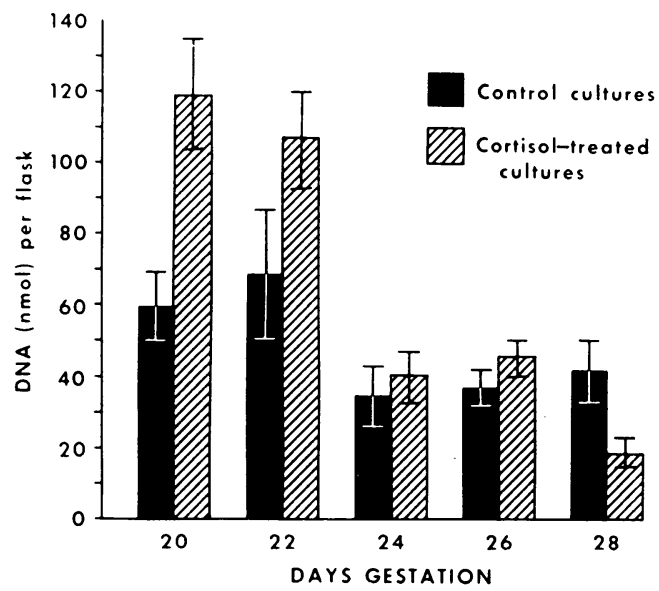

Figure 4 Effect of cortisol on the DNA content of fetal rabbit lung cell cultures after $72 \mathrm{~h}$ for cells prepared from the 20th to the 28th days of gestation. Open bars illustrate control cultures, and shaded bars, cultures grown in the presence of cortisol $(5.5 \mu \mathrm{M})$. The height of each bar represents the mean $\pm \mathrm{SD}$ of five observations from each of two litters. The growth promoting effect of cortisol on days 20 and 22 and the growth inhibition on day 28 are readily apparent. dissolved in $10 \mathrm{ml}$ of chloroform and washed five times with $5 \mathrm{ml}$ of water to remove excess mercuric acetate. The samples were then chromatographed on Silica Gel $\mathrm{H}$ in the system chloroform: methanol: water $(70: 30: 4)$ (23), separating the disaturated lecithins from the acetoxymercurimethoxy adducts of mono- and diunsaturated lecithins. After location of the spots by autoradiography, the fractions were eluted with $10 \mathrm{ml}$ of the solvent system followed by $10 \mathrm{ml}$ of chloroform: methanol (1:1) and counted. Results were expressed as the percentage of the carbon-14 label recovered in the saturated lecithin fraction at each gestational age from cells grown in the presence and in the absence of cortisol.

Counting of radioactivity. Samples for counting were dried under a stream of air and redissolved in $15 \mathrm{ml}$ of toluene-phosphor solution. Counts were taken in a Packard TriCarb Liquid Scintillation Spectrometer, Model 4322 (Packard Instrument Co., Inc., Downers Grove, Ill.), with an efficiency for ${ }^{14} \mathrm{C}$ of $60 \%$. Counting time was selected to provide an error of less than $5 \%$. These procedures have been described in detail previously (24).

Calculation of results. The incorporation of $\left[{ }^{14} \mathrm{C}\right]$ palmitate into phospholipids was expressed in terms of the mass of palmitate incorporated per unit of DNA (picomole per micromole). This provided correction for variations in number of cells. Results were obtained in five replicate cultures from each of two litters for each gestational age (a total of ten control observations and of ten with cortisol). The mean and standard deviation was calculated for each group of observations. Statistical differences between control studies and studies using cortisol at any given gestational age were established by Student's $t$ test.

\section{RESULTS}

Cell yield, viability, and plating efficiency. The lung cell population released under the conditions described

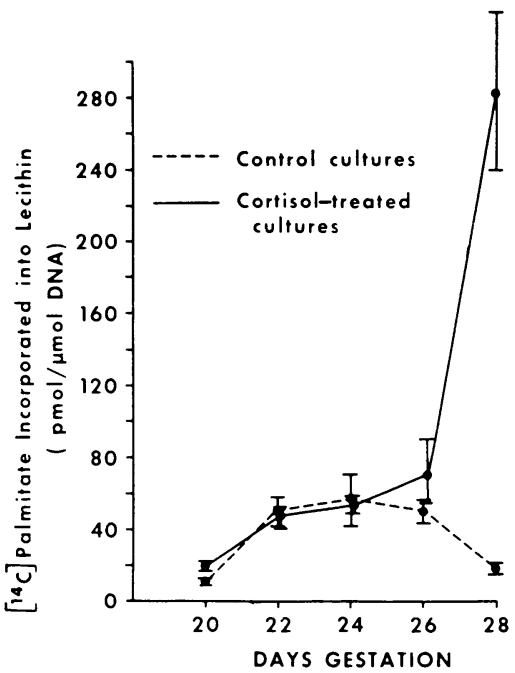

FIGURE 5 Effect of cortisol on the incorporation of $\left[1{ }^{14} \mathrm{C}\right]$ palmitate into lecithin. The results are expressed as picomole incorporated per micromole DNA. Each point represents the mean $\pm S D$ of five observations from each of two litters. The dotted line represents control cultures, and the solid line, cultures grown in the presence of cortisol (5.5 $\mu \mathrm{M})$. 
TABLE I

Effect of Cortisol on the DNA Content and Incorporation of $\left[{ }^{14} \mathrm{C}\right]$ Palmitate into Lecithin and

Sphingomyelin in Cultures of Fetal Rabbit Lung Cells from the 20th to 28th day

of Gestation. The Percentage of Recovered $\left[{ }^{14} \mathrm{C}\right]$ Lecithin which

Was Saturated Is Also Shown

\begin{tabular}{clccrr}
\hline Gestation & Culture conditions & DNA & Lecithin* & \% Saturated & Sphingomyelin* \\
\hline days & & $n$ mol & & & \\
20 & Control & $59.8 \pm 8.9$ & $10.5 \pm 2.5$ & 72.4 & $3.9 \pm 1.4$ \\
20 & Cortisol treated & $118.7 \pm 15.7$ & $20.0 \pm 3.0$ & 71.6 & $3.3 \pm 1.2$ \\
22 & Control & $69.2 \pm 17.2$ & $49.9 \pm 7.2$ & 71.5 & $10.1 \pm 2.1$ \\
22 & Cortisol treated & $106.7 \pm 13.3$ & $47.0 \pm 14.1$ & 76.3 & $6.5 \pm 1.1$ \\
24 & Control & $35.5 \pm 7.4$ & $57.0 \pm 13.6$ & 82.1 & $10.1 \pm 2.7$ \\
24 & Cortisol treated & $40.2 \pm 7.2$ & $54.1 \pm 6.6$ & 82.4 & $6.6 \pm 1.8$ \\
26 & Control & $36.4 \pm 5.6$ & $51.2 \pm 5.5$ & 97.6 & $8.2 \pm 3.5$ \\
26 & Cortisol treated & $45.4 \pm 5.1$ & $72.8 \pm 16.2$ & 95.1 & $9.3 \pm 4.2$ \\
28 & Control & $42.0 \pm 8.5$ & $19.7 \pm 3.1$ & 92.0 & $9.3 \pm 5.6$ \\
28 & Cortisol treated & $19.3 \pm 4.0$ & $286.8 \pm 47.0$ & 98.0 & $2.3 \pm 3.9$ \\
\hline
\end{tabular}

* Picomole of $\left[{ }^{14} \mathrm{C}\right]$ palmitate incorporated into total lecithin (or sphingomyelin) fraction per micromole of DNA after $24 \mathrm{~h}$ incubation.

above was of sufficient size to prepare ten culture flasks from the pooled lungs of a single litter at the earliest gestational age studied (20 days). Cell yield increased with advancing gestational age in proportion to overall fetal growth and lung growth and averaged $1.25 \mu \mathrm{mol}$ of DNA per $g$ tissue (wet wt). Based upon the trypan blue dye exclusion test $(19$, p. 283$)$, the dispersed cells were consistently viable to the extent of $90 \%$. Plating efficiency, as determined by the DNA content of the medium removed after the first $24 \mathrm{~h}$ (i.e., of the cells which failed to attach to the culture flask), did not differ between control and cortisol treated cultures at any gestational age, averaging $75 \%$.

Cell morphology. The cells isolated by this procedure showed morphological changes with gestational age. At the earliest gestational age (20 days) they appeared mainly as spindle-shaped fibroblastic cells (Fig. 1), while with advancing gestational age, an increasing proportion of the cells were epithelial in nature (Fig. 2). The epithelial cells tended to grow in patches, surrounded by the fibroblastic cell type. Epithelial growth seemed to be favored by the presence of cortisol in the culture media (Fig. 2).

Effect of cortisol on cellular growth. Cell growth either in the presence or in the absence of cortisol (5.5 $\mu \mathrm{M}$ ) was compared by measuring the accumulation of DNA in individual flasks after $72 \mathrm{~h}$ in culture. At this time, as is shown in Fig. 3, all cultures were in the exponential phase of growth so that DNA content at $72 \mathrm{~h}$ indeed reflects differences in cellular growth. Cortisol had a marked effect on growth as shown in Fig. 4, which illustrates the mean and standard deviation of observations made on ten control cultures and ten cultures sub- jected to cortisol (five from each of two litters) at each gestational age studied. At the concentration of cortisol used, cellular growh was enhanced by $100 \%$ on day 20 $(P<0.001)$ and by $65 \%$ on day $22(P<0.001)$. From this gestational age on, cortisol did not significantly enhance cellular growth, values for control and cortisol treated cultures being $35.5 \pm 7.4$ nmol DNA per flask vs. $40.2 \pm 7.2$ on the 24 th day and $36.4 \pm 5.6$ vs. $45.4 \pm 5.1$ on the 26th day. On the 28th day, however, the DNA content of cultures grown in the presence of cortisol was reduced by a factor of $2(P<0.001)$.

Effect of cortisol on the biosynthesis of phospholipids. Since the effect of cortisol on lung maturation in vivo is generally attributed to the synthesis of surface active (saturated) lecithin, studies were undertaken to investigate whether addition of cortisol to the lung cell cultures would affect lecithin synthesis as measured in the culture media. To this effect, $\left[{ }^{14} \mathrm{C}\right]$ palmitate incor-

TABLE II

Effect of 11-Deoxycortisol on the Incorporation of $\left[{ }^{14} \mathrm{C}\right]$ Palmitate into Lecithin by 28 Day Fetal Rabbit Lung Cells after 7 Days in Culture, Expressed as Picomole of Palmitate Incorporated per Flask

\begin{tabular}{lccc}
\hline \multicolumn{1}{c}{ Steroid(s) added } & $\begin{array}{c}\text { Observa- } \\
\text { tion I }\end{array}$ & $\begin{array}{c}\text { Observa- } \\
\text { tion II }\end{array}$ & Mean \\
\hline None (control) & 6.2 & 13.8 & 10.0 \\
Cortisol $(5.5 \mu \mathrm{M})$ & 31.4 & 36.8 & 34.1 \\
11-Deoxycortisol $(5.5 \mu \mathrm{M})$ & 11.9 & 8.6 & 10.2 \\
11-Deoxycortisol $(55 \mu \mathrm{M})$ & 12.1 & 9.6 & 10.8 \\
11-Deoxycortisol $(55 \mu \mathrm{M})$ & 18.1 & 14.4 & 16.2 \\
$\quad$ plus cortisol $(5.5 \mu \mathrm{M})$ & & & \\
\hline
\end{tabular}


poration into lecithin and sphingomyelin was studied as a function of gestational age from the 20 th to the 28 th day. The results presented in Fig. 5 and Table $I$ are expressed as picomole of palmitate incorporated per micromole DNA. The incorporation of palmitate into lecithin in control cultures was $10.5 \pm 2.5 \mathrm{pmol} / \mu \mathrm{mol}$ DNA on the 20th day and gradually increased to $57.0 \pm$ 13.6 on the 24 th day. Corresponding values for cultures exposed to cortisol were not significantly different. On day 26, however, cortisol increased palmitate incorporation $25 \%(P<0.01)$. This effect was very markedly enhanced on day 28 due, in part, to a decreased incorporation of palmitate by control cultures $(19.7 \pm 3.1)$ but to a much greater extent by a striking increase in palmitate incorporation by cultures exposed to cortisol $(286.8 \pm 47.0)(P<0.001)$. The proportion of lecithin which was saturated (and therefore surface active) showed a slight rise with gestational age (Table I). At the two stages ( 26 and 28 days) where cortisol increased lecithin synthesis, over $90 \%$ of the recovered lecithin was saturated.

This effect of cortisol was examined by growing 28 day fetal lung cells in the presence of either equimolar concentrations or ten times this concentration of 11deoxycortisol (17 $\alpha, 21$-dihydroxypregn-4-ene-3,20-dione) and examining the incorporation of $\left[{ }^{14} \mathrm{C}\right]$ palmitate into lecithin after 7 days in culture, at which time all cultures had reached confluence. The results, presented in Table II, show that 11-deoxycortisol, even in amounts tenfold greater than those of cortisol, does not enhance lecithin biosynthesis but markedly reduces the stimulatory effect of cortisol.

Cortisol had no detectable effect on the incorporation of $\left[{ }^{14} \mathrm{C}\right]$ palmitate into sphingomyelin over the same range of gestational ages (Table $\mathrm{I}$ ).

\section{DISCUSSION}

The expression "cellular growth" as used in the context of this report refers to cell mitosis and therefore implies an increase in cell numbers. Since the DNA content of any single-nucleated cell is constant, as opposed to protein or to other cell constituents, which may vary independently of the number of cells present, the quantitative measurement of DNA becomes the best available index of cell proliferation or growth as defined above.

The stimulatory effect of cortisol that we observed on the growth of rabbit fetal lung cells was most significant at the earliest gestational age studied. It was not apparent beyond the 22nd day and was, in fact, reversed on the 28th day, at which time the steroid exerted a significant growth inhibition. These observations are in general agreement with the growth promoting activity of cortisol on cultures of midterm human fetal lung cells (15) and with the report that administration of cortisol hemisuccinate to the fetal rabbit on day 24 inhibits pulmonary cell division as assessed 2 days later (25).

Although cortisol is known to possess a catabolic effect in vitro, as well as in vivo (26), it has been reported that the presence of cortisol or dexamethasone was necessary for survival of fetal mouse hepatocytes grown in a chemically defined medium (27). Cortisol has also been observed to prolong the in vitro lifespan of an established line (WI-38) of human embryonic lung cells (28). It is unlikely, however, that the growthpromoting effect of cortisol reported here for rabbit fetal lung cells at the earliest gestations studied merely reflects a role of the steroid as an adjunct to the maintenance of these cells under in vitro conditions. If this were the case, one would expect that lung cells isolated by the same procedure, grown under the same conditions, and studied biochemically within the same span of time after implantation would similarly respond to the steroid, irrespective of gestational age. The marked difference of growth effect of cortisol from day 20 to 28 suggests changes of cell responsiveness to the hormone as a function of gestational age. Moreover, under essentially identical conditions, while cortisol was shown to enhance the growth of midterm human fetal lung cells, this effect was not manifested in a mixed population of cells prepared from the embryologically closely related fetal larynx, trachea, and esophagus (15). The definition of the processes by which cortisol induces the proliferation of these cells could prove rewarding in the context of the mechanism of action of the hormone.

It is now well established that "lung maturity" is correlated with increased production of saturated lecithin by type II alveolar cells $(29,30)$. This phospholipid can be produced by two biosynthetic pathways $(31,32)$ involving either the incorporation of cytidine diphosphocholine into a saturated $\alpha, \beta$-diglyceride or by the introduction of three methyl groups into phosphatidyl ethanolamine. In the fetal rabbit, the former pathway is by far the most important (30).

Previous studies have demonstrated that when administered during the latter part of gestation glucocorticoids hasten pulmonary maturation in the lamb, rabbit, and Rhesus monkey (4-8). More recently, a marked increase in CDP-choline transferase activity was observed in homogenates of fetal rabbit lungs, $48 \mathrm{~h}$ after the intrafetal injection of $9 \alpha$-fluoroprednisolone or of cortisol (9). This report is of particular interest since this enyme catalyses the rate-limiting step of choline incorporation into lecithin. Our observation that cortisol markedly increases the incorporation of palmitate into lecithin on the 26th and 28th days appears to be in keeping with these findings. The $\left[{ }^{14} \mathrm{C}\right]$ palmitate was incorporated mainly into saturated lecithin, as would be expected since dipalmityl lecithin is the major component 
of the pulmonary surfactant (3). However, since the label would appear on lecithins with at least one palmitic acid moiety, the percentage saturation as measured in this study is probably spuriously high and should not be taken to represent the saturated proportion of the total (unlabeled) lecithin pool.

The morphological changes noted in culture in the presence of cortisol may represent a basic change in the cell population under study. Indeed, steroid treatment in vivo has been shown by Wang, Kotas, Avery, and Thurlbeck (33) to result in dramatic morphological changes. One can only speculate as to whether the results noted are due to enzyme induction by cortisol or to an increase in the number of functioning type II cells.

11-deoxycortisol was devoid of effect on lecithin formation even at concentrations tenfold higher than those of cortisol, but appeared to reduce the cells' responsiveness to cortisol. This is of particular interest, since Giannopoulos has shown (34) that 11-deoxycortisol competes for the glucocorticoid-binding protein in fetal rabbit lung. It seems possible that 11-deoxycortisol binds to form an inactive steroid-receptor complex thus interfering with the binding of cortisol to this receptor.

Since only the culture media and not the cells were examined for the presence of $\left[{ }^{14} \mathrm{C}\right]$ lecithin, the effect noted probably reflects both the biosynthesis of lecithin and its release from the cells. If this view were to be substantiated and if lecithin synthesis as measured in the culture medium were to be more specifically defined in terms of secretion, the present experimental approach would provide a useful model for studying the release of surface active material from pulmonary cells. Such studies could prove rewarding, since independent mechanisms have been suggested for the control of lecithin biosynthesis and its release $(35,36)$.

The decrease of palmitate incorporation into lecithin seen in the control cultures on days 26 and 28 was unexpected. The possibility that a relative lack of glucocorticoid is, in fact, responsible must be considered in view of the ready reversal of this decline in cultures grown in the presence of cortisol. The absence of other factors such as thyroxine $(37,38)$ must also be considered.

These observations suggest that cortisol has two separate affects on developing fetal lung cells, depending upon the age of the fetus at the time of exposure. It enhances cellular growth at the earlier gestations studied and slows growth near term. Though maturation, in terms of increased incorporation of palmitate into saturated lecithin is enhanced by cortisol, this effect is not manifested before day 26 , at which time alveolar stability is already commencing in the fetal rabbit (30). The precise definition of the mechanism by which these changes are induced will likely provide new insights into cell responsiveness to hormones with respect to growth and differentiation.

\section{ACKNOWLEDGMENTS}

The authors wish to express their appreciation to Drs. M. E. Avery and H. W. Taeusch. Jr. for their encouragement.

This work was supported by a grant from the Medical Research Council of Canada.

\section{REFERENCES}

1. Avery, M. E., and J. Mead. 1959. Surface properties in relation to atelectasis and hyaline membrane disease. Am. J. Dis. Child. 97 : 517.

2. Clements, J. A. 1962. Surface phenomena in relation to pulmonary function. (Sixth Bowditch Lecture). Physiologist. 5 : 11.

3. Buckingham, S., and M. E. Avery. 1962. Time of appearance of lung surfactant in the foetal mouse. $\mathrm{Na}$ ture (Loind.). 193: 688 .

4. deLemos, R. A., D. W. Shermeta, J. H. Knelson, R. Kotas, and M. E. Avery. 1970. Acceleration of appearance of pulmonary surfactant in the fetal lamb by administration of corticosteroids. Am. Rev. Respir. Dis. 102 : 459.

5. Kotas, R. V., and M. E. Avery. 1971. Accelerated appearance of pulmonary surfactant in the fetal rabbit. J. Appl. Physiol. 30: 358.

6. Motoyama, E., M. Orzalesi, Y. Kikkawa, M. Kaibara, B. Wu, C. J. Zigas, and C. D. Cook. 1971. Effect of cortisol on the maturation of fetal rabbit lungs. Pediatrics. 48: 547.

7. Taeusch, H. W., Jr., M. Heitner, and M. E. Avery. 1972. Accelerated lung maturation and increased survival in premature rabbits treated with hydrocortisone. Am. Rev. Respir. Dis. 105: 971.

8. deLemos, R. A., and G. W. McLaughlin. 1973. Induction of the pulmonary surfactant in the fetal primate by the intrauterine administration of corticosteroids. Pediatr. Res. 7 : 197. (Abstr.).

9. Farrell, P. M., and R. D. Zachman. 1973. Induction of choline phosphotransferase and lecithin synthesis in the fetal lung by corticosteroids. Science (Wash. D. C.). 179: 297.

10. Liggins, G. C., and R. N. Howie. 1972. A controlled trial of antepartum glucocorticoid treatment for prevention of the respiratory distress syndrome in premature infants. Pediatrics. 50: 515.

11. Spellacy, W. N., W. C. Buhi, F. C. Riggatt, and K. L. Holsinger. 1973. Human amniotic fluid lecithin/sphingomyelin ratio changes with estrogen or glucocorticoid treatment. Am. J. Obstet. Gynecol. 115: 216.

12. Baden, M., C. R. Bauer, E. Colle, G. Klein, H. W. Taeusch, Jr., and L. Stern. 1972. A controlled trial of hydrocortisone therapy in infants with respiratory distress syndrome. Pediatrics. 50: 526.

13. Ballard, P. L., and R. A. Ballard. 1972. Glucocorticoid receptors and the role of glucocorticoids in fetal lung development. Proc. Natl. Acad. Sci. U. S. A. 69: 2668.

14. Giannopoulos, G., S. Mulay, and S. Solomon. 1972. Cortisol receptors in rabbit fetal lung. Biochem. Biophys. Res. Commun. 47: 411.

15. Smith, B. T., J. S. Torday, and C. J. P. Giroud. 1973. The growth promoting effect of cortisol on human fetal lung cells. Steroids. $22: 515$. 
16. Ham, R. G. 1963. An improved nutrient solution for diploid chinese hampster and human cell lines. Exp. Cell Res. 29: 515.

17. Klein, G. P., M. deLevie, and C. J. P. Giroud. 1972. Simultaneous measurement of plasma cortisol, cortisone, corticosterone, corticosterone sulfate, and 11-deoxycorticosterone sulfate by competitive protein binding assays during the perinatal period. Steroids. 19: 275.

18. Umbreit, W. 1959. Manometric Techniques. Burgess Publishing Co., Minneapolis. 149.

19. Parker, R. C. 1961. Methods of Tissue Culture. Harper \& Row, Publishers, New York. 3rd edition. 131, 283.

20. Burton, K. 1956. A study of the conditions and mechanism of the diphenylamine reaction for the colorimetric determination of deoxyribonucleic acid. Biochem. J. $62: 315$.

21. Gluck, L., M. V. Kulovich, and S. J. Brody. 1966. Rapid quantitative measurement of lung tissue phospholipids. J. Lipid Res. $7: 570$.

22. Mangold, H. K. 1961. Thin-layer chromatography of lipids. J. Am. Oil Chem. Soc. 38: 708.

23. Blank, M. L., L. J. Nutter, and O. S. Privett. 1966. Determination of the structure of lecithins. Lipids. 1: 132.

24. Stachenko, J., C. Laplante, and C. J. P. Giroud. 1964. Double isotope derivative assay of aldosterone, corticosterone, and cortisol. Can. J. Biochem. 42: 1275.

25. Carson, S. H., H. W. Taeusch, Jr., and M. E. Avery. 1973. Inhibition of lung cell division after hydrocortisone injection into fetal rabbits. J. Appl. Physiol. 34: 660.

26. Berliner, D. L., and A. G. Ruhmann. 1966. Comparison of the growth of fibroblasts under the influence of $11 \beta$-hydroxy and 11-keto corticosteroids. Endocrinology. 78: 373.

27. Waymouth, C., H. W. Chen, and B. G. Wood. 1971. Characteristics of mouse liver parenchymal cells in chemically defined media. In Vitro. 6: 371. (Abstr.).
28. Cristofalo, V. J., D. Kobler, J. Kabakjian, J. MacKessy, and B. Baker. 1971. The effect of hydrocortisone on the proliferation of human diploid cell line WI-38. In Vitro. 6: 396. (Abstr.).

29. Gluck, L., E. K. Motoyama, H. L. Smits, and M. V. Kulovich. 1967. The biochemical development of surface activity in mammalian lung. Pediatr. Res. 1: 237.

30. Kikkawa, Y., E. K. Motoyama, and L. Gluck. 1968. Study of the lungs of fetal and newborn rabbits. Morphological, biochemical, and surface physical development. Am. J. Pathol. 52 : 177.

31. Morgan, T. E. 1971. Biosynthesis of pulmonary surfaceactive lipid. Arch. Intern. Med. 127: 401.

32. Tombropoulos, E. G. 1971. Lipid synthesis by lung subcellular particles. Arch. Intern. Med. 127: 408.

33. Wang, N. S., R. V. Kotas, M. E. Avery, and W. M. Thurlbeck. 1971. Accelerated appearance of osmiophilic bodies in fetal lungs following steroid injection. $J$. Appl. Physiol. 30: 362.

34. Giannopoulos, G. 1973. Glucocorticoid receptors in lung. I. Specific binding of glucocorticoids to cytoplasmic components of rabbit fetal lung. J. Biol. Chem. 248: 3876.

35. Goldenberg, V. E., S. Buckingham, and S. C. Sommers. 1967. Pulmonary alveolar lesions in vagotomized rats. Lab. Invest. 16: 693.

36. Goldenberg, V. E., S. Buckingham, and S. C. Sommers. 1969. Pilocarpine stimulation of granular pneumocyte secretion. Lab. Invest. 20 : 147.

37. Wu, B., Y. Kikkawa, M. M. Orzalesi, E. K. Motoyama, M. Kaibera, C. J. Zigas, and C. D. Cook. 1971. Accelerated maturation of fetal rabbit lungs by thyroxine. Physiologist. 14: 253. (Abstr.).

38. Redding, R. A., W. H. J. Douglas, K. R. Wunschell, and M. Stein. 1971. Influence of thyroid hormone upon lung ultrastructure and surfactant production. Fed. Proc. 30: 619a. 